\title{
12 Emerging opportunities, challenges and constraints in the Chinese food industry
}

\author{
Mana Bolin and Matilde Cassin
}

\section{Introduction}

Given the phenomenon of growing urbanization, the pressure on food demand for an increasing population as well as changing diet, China has had to resort to imports, becoming a net importer of food. In the absence of external flows, this scenario is set to continue and could result in a future Malthusian scenario.

Starting from these premises, the Chapter, based on three core areas (production, consumption and trade), aims to analyze the current situation, identifying opportunities, challenges and constraints that could prevent the development of the Chinese food industry. Firstly, the study provides an analysis of the context in which Chinese food companies evolve, analyzing supply (with a focus on the main food and beverages companies), consumption, and trade trends. Then, an identification of the main policies involving the food sector is outlined. Moreover, the Chapter focuses on the obstacles that could affect the sustainable development of the Chinese food industry, such as increased urbanization, climate change threats and conflicts for limited natural resources (particularly land and water). A summary of the findings of this study and some recommendations for the Chinese food industry conclude the Chapter.

The sources used are mainly sources referred to at an international level: The World Bank and WTO in order to define socio-economic profiles and trends; the FAOSTAT as some environmental issues. ${ }^{1}$ At the national level, data have been extracted from the Chinese National Bureau of Statistics and from the China Statistical Yearbook (2014).

\section{The context}

The role of China in the global economy has been increasing and becoming more and more important in recent years, thanks to a gradual transition to a marketbased economy and consequent rapid economic development and strong social changes.

However, as shown in Figure 12.1, after years of constant economic growth, recently China seems to be facing a new phase, characterized by deceleration (Lee 


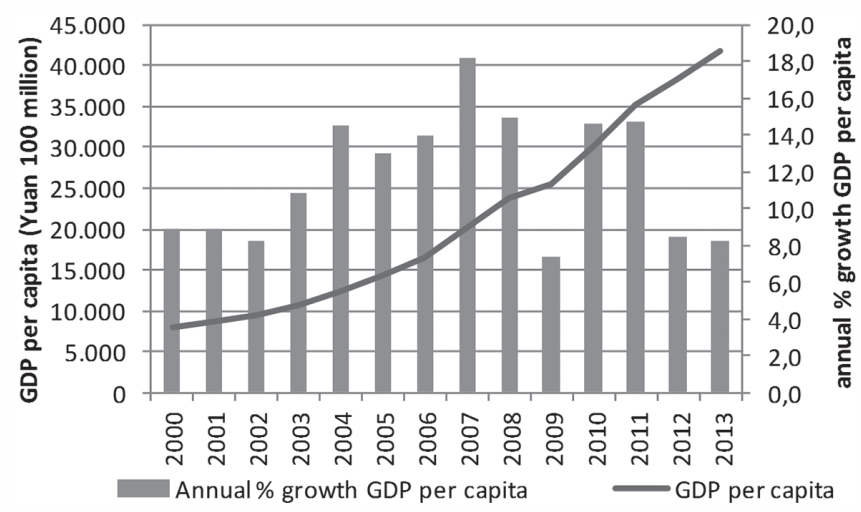

Figure 12.1 China's GDP per capita and GDP annual growth per capita

Source: Authors' elaboration on China Statistical Yearbook data, 2014

et al., 2016): GDP in 2012 and 2013 have grown at the lowest rate since 2000. Moreover, 2015 was the year of the Chinese stock market crash. China seems to have entered a new era, as it seeks to transition from an investment-and exportled economy to consumption-led growth. Despite the inevitable bumps and backtracking along this path, this transformation is expected to result in economic growth that could be more sustainable in the long term (USDA, 2015).

Besides the growth of GDP per capita (which has quintupled in value between 2000 and 2013, with an annual growth rate that reaches $10 \%$ on average, Figure 12.1), important socio-demographic changes have occurred. The Chinese population, while continuing to grow (going from 500 million in 1959 to 1.37 billion in 2014 , equal to $19.48 \%$ of the world's population), has slowed its growth rate since the $1970 \mathrm{~s}$ (from an average of six children to 1.4 children per woman in 2013 and the birth rate from an average of 44 births per 1,000 inhabitants to 12 births) due to the one-child policy (一胎 制, yìtaiizhì) (Figure 12.2). ${ }^{2}$ The progressive aging of the population is one of the dark side effects of the one-child policy, as well as the imbalance of the country's overall gender ratio towards males (roughly between 3\% and 4\% more males than females). A third consequence of the policy were instances where the births of subsequent children after the first went unreported or were hidden from authorities. Those children, most of whom were undocumented, faced difficulties in obtaining education and employment.

In 2015, the Chinese news agency Xinhua (www.xinhuanet.com) announced the intention of the government to abolish the one-child policy and Chinese families could have two children without incurring the payment of penalties.

Furthermore, there has been a progressive population shift from rural to urban areas (Figure 12.3); in particular, the population living in urban areas, which has steadily continued to increase, exceeds those living in rural areas (in marked decline from the mid-1990s). 


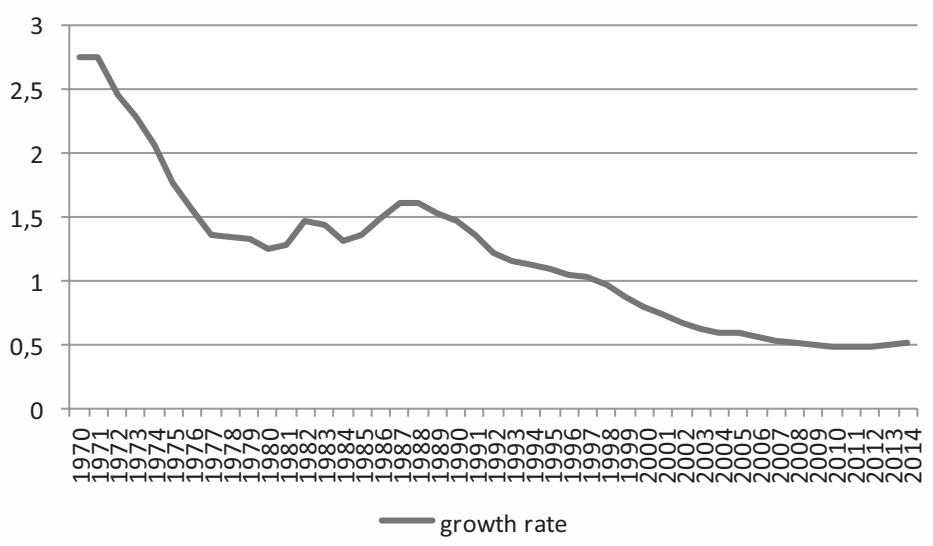

Figure 12.2 China's population growth rate (1979-2014)

Source: Authors' elaboration on World Bank data, 2014

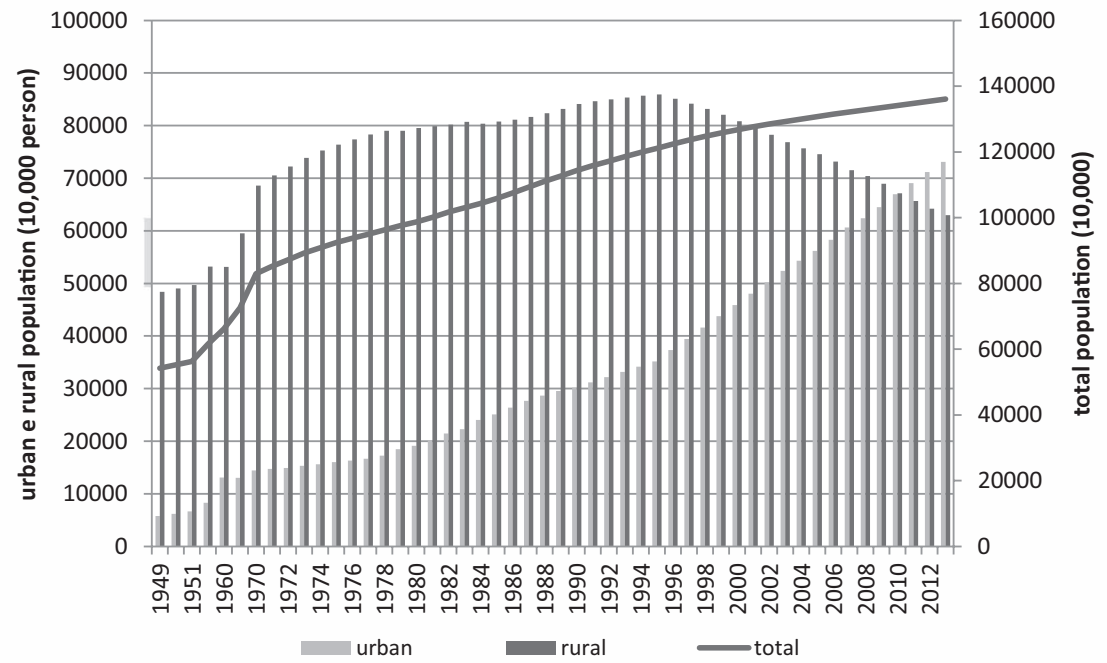

Figure 12.3 China's population trend (1949-2013): total population (right) and urban/ rural population (left)

Source: Authors' elaboration on China Statistical Yearbook data, 2014

In 2014 the Chinese authorities adopted the National New-type Urbanization Plan (2014-2020) aimed at moving 250 million rural residents to newly built cities by 2020 to set off a new wave of growth, the effects of which could weigh on generations to come. The ultimate goal of the government's modernization plan is to have $70 \%$ of the Chinese population in cities by 2025 and, as a consequence, 


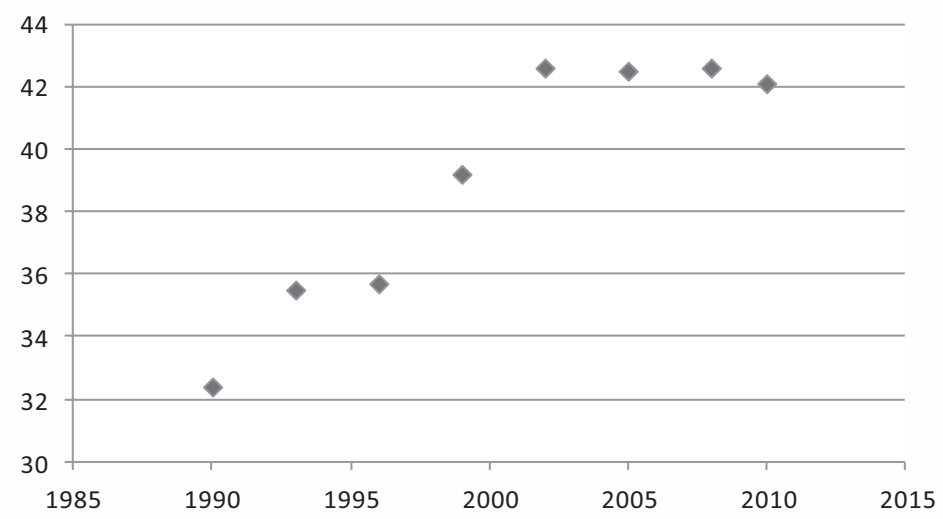

Figure 12.4 China's inequality trend: GINI index

Source: Authors' elaboration on World Bank - Poverty and Equity databank, 2014

land disputes with farmers who do not wish to relocate could exponentially increase (Li, 2014).

Urbanization is only one of the challenges that Chinese rapid economic ascendancy has brought abought, along with the exploitation of natural resources and consequent environmental issues, social inequality and external imbalances.

Despite fast economic growth, China still remains a developing country, with a per capita income that is still a fraction of those in advanced countries and with a high and increasingly unequal income distribution among the population. Although the number of poor is steadily declining - but still high (Figure 12.5) social disparities are rising, as shown by the GINI index trend (Figure 12.4) and by the distribution of income among the population: in 2010, the wealthiest had $47 \%$ of the total income compared to $40.7 \%$ in $1990 .^{3}$

\section{Food supply}

China is the world's fourth largest country by total land area behind Russia, Canada and the USA with a land area equal to 9.4 million $\mathrm{km}^{2}$, but has just $10 \%$ of the world's agricultural land and 7\% of the world's fresh water (ANZ, 2013). Severe pollution issues exacerbate this scarcity, particularly in North China.

According to the literature (Lam et al., 2013), only about $40 \%$ of the available Chinese arable land can be considered most suitable for crop production, with much of the remaining area subject to environmental stresses such as drought and high salinity content.

Chinese arable land data vary according to differing sources. FAOSTAT statistics highlight a lower land area compared to that reported by the Chinese government, (equal to 121.7 million hectares in late 2012), and under the so-called 'red 


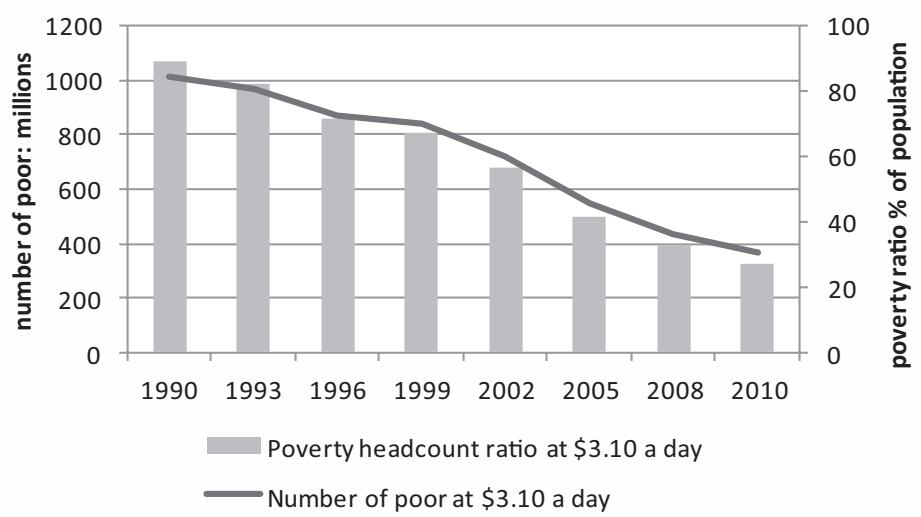

Figure 12.5 People living on less than $\$ 3.10$ a day in China

Source: Authors' elaboration on World Bank - Poverty and Equity databank, 2014

line ${ }^{34}$ (耕地 红线, gēngdihóngxiàn) of 120 million hectares (OECD, FAO, 2013), required for food self-sufficiency.

The size (1990-2010) of available arable land in China (Figure 12.6) is steadily decreasing, while the overall agricultural area is stable. In 2010 arable land represented $10 \%$ of the total land area and is less than 0.1 ha per capita (less than $40 \%$ of the world average). This negative trend can be largely traced to a variety of climatic, environmental and human factors which caused land use conflicts and soil degradation (Asia has the highest proportion of soil degradation of the global regions, (FAO, 2015)), land diversion for bio-fuel production and unequal land distribution (Zhao, 1986).

As a reaction to the decreasing farmland, the Government approved in 1994 the 'Basic Farmland Protection Regulations' which prohibited basic farmland conversion to non-agricultural activities and mandated counties and townships to designate basic farmland protection districts in accordance with provincial farmland protection plans $^{5}$ (Ding, 2003). According to the several times modified and integrated Land Administration Law (LAL), land acquisition can be carried out only when the purpose of the acquisition is to serve public interests, even if commercial projects accounted for 22\% of all acquisitions in 2000-2001 (Ding, 2007).

The Chinese Constitution states that land is collectively owned by farmers but contracted by individual households (Xiwen, 2006). As a consequence, the Chinese agricultural sector is characterized by extreme fragmentation. According to the agricultural census in China, in 2007 there were almost 200 million farms (FAO, 2013 ), representing $35 \%$ of all the farms in the world, most of them (93\%) less than 1 ha, $5 \%$ between 1 and 2 ha, $2 \%$ between 5 and 10 ha and only $0.4 \%$ of the farms were larger than 10 ha. Farming in China has always been very labor intensive.

Despite the shortage of usable natural resources, agriculture has played a very important role in China's economic growth since the ends of the 1970s. In the 


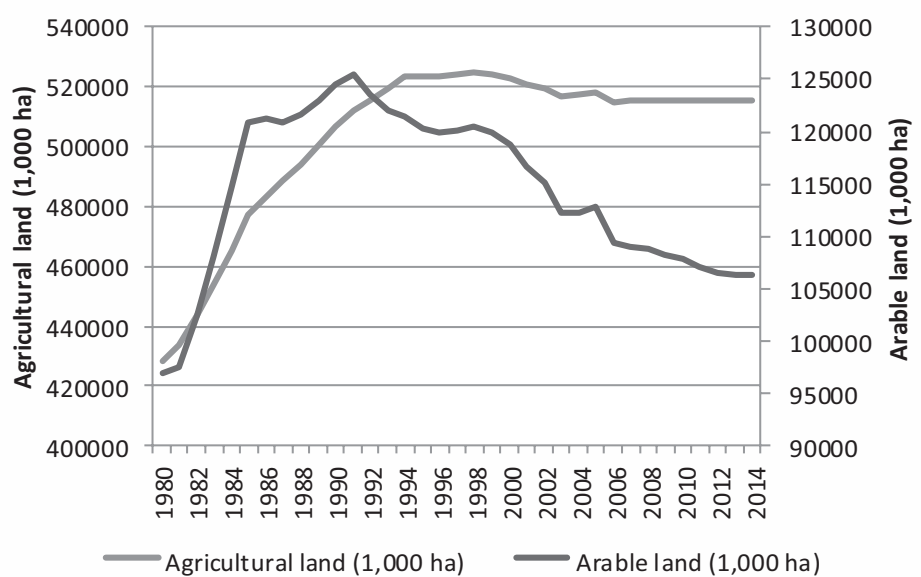

Figure 12.6 Agricultural land*and arable land** in China, trend

* Agricultural land refers to the share of the land area that is arable, under permanent crops, and under permanent pastures. Land under permanent crops is land cultivated with crops that occupy the land for long periods and need not be replanted after each harvest, such as cocoa, coffee, and rubber. This category includes land under flowering shrubs, fruit trees, nut trees, and vines, but excludes land under trees grown for wood or timber. Permanent pasture is land used for five or more years for forage, including natural and cultivated crops.

** Arable land includes land defined by the FAO as land under temporary crops (double-cropped areas are counted once), temporary meadows for mowing or for pasture, land under market or kitchen gardens, and land which is temporarily fallow. Land abandoned because of shifting cultivation is excluded.

Source: Authors' elaboration on FAOSTAT data, 2015

first reform period (1978-1984) agricultural GDP grew very quickly and also its yields: agricultural labor productivity grew by $5-10 \%$ per year (Park, 2009), so China became one of the world's largest food producers. Despite the decline in surface area, total cereal production is steadily growing - in particular corn production is recording the highest growth (Figure 12.7) - and China is still selfsufficient in a number of basic strategic crops and food sources, providing food security and ensuring social stability.

However, over time, the percentages of the agricultural work force and GDP of the total decreased (Liu et al., 2012): from $70 \%$ of employment and $30 \%$ of GDP in 1980 to little more than $30 \%$ of employment and less than $10 \%$ of total GDP in 2014. Pollution (of water and soil) has contributed to this trend. Also, China has been (and is) facing criticism about the quality and safety of its domestic and export food products.

During the past decade, the food industry in China has rapidly developed and expanded. In 2013, China is the world's largest consumer market for food and beverage products (Figure 12.8) surpassing the United States since 2011 and the second-fastest growing Asian F\&B market with an average annual growth rate of 


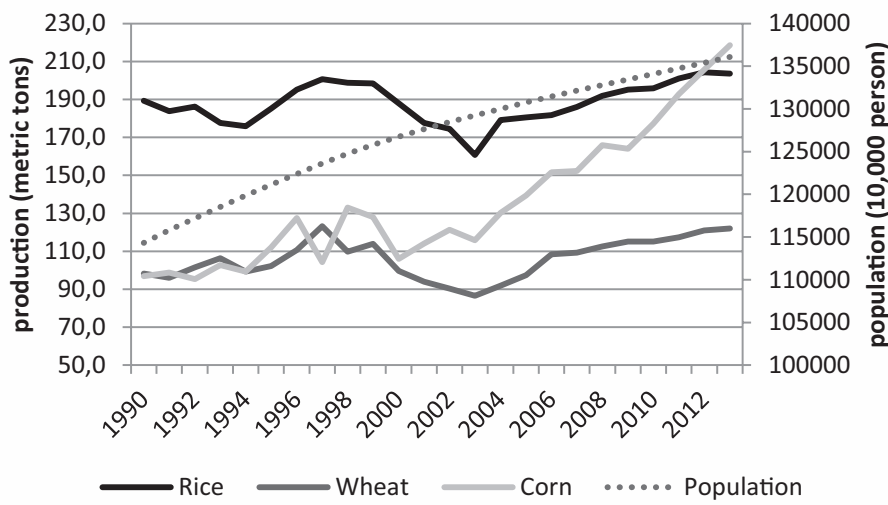

Figure 12.7 Main cereals production in China (10,000 tons)

Source: Authors' elaboration on FAOSTAT data

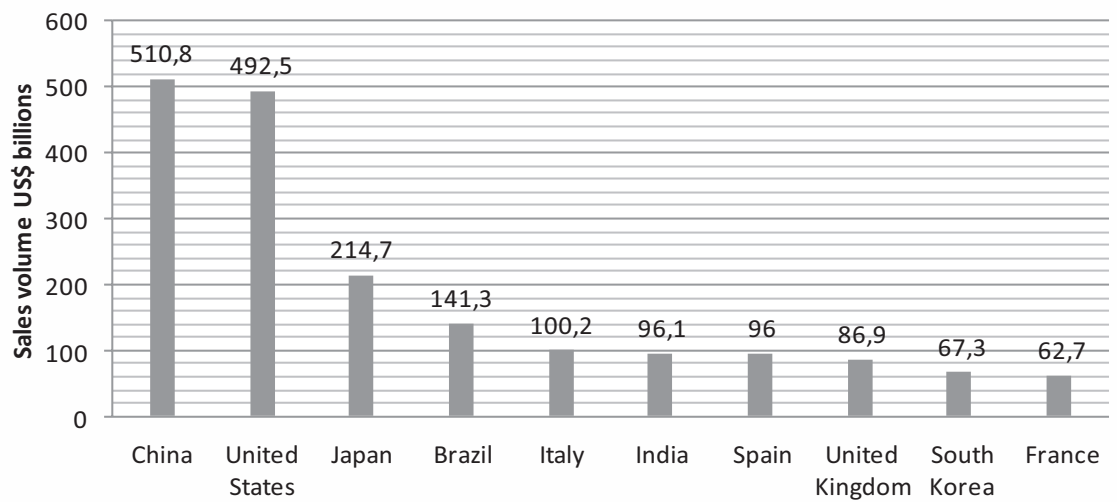

Figure 12.8 Foodservice Markets Worldwide in 2013 (sales volume, US\$ Billions)

Source: Authors' elaboration on Euromonitor International, 2014

$30 \%$ between 2009 and 2014. Modern retail formats are profiting from this development (Euromonitor, 2014).

A substantial proportion of processed food is produced and consumed in coastal areas. This is due to strong urbanization and higher total consumer purchasing power in these regions. In inland areas, due to lower urbanization and income, high-value processed foods are consumed mainly in big cities. A rule of thumb is that the majority of food is produced in the North (above Shanghai) and consumed in the South.

The food industry structure is dualistic: a large number of small businesses are matched by large companies with predominantly Chinese capital and whose 
market is dominated by domestic demand. The top 10 food and beverage companies are listed in the Appendix.

Expanding food service expenditure is the result of greater disposable income and of new and modern ways of life. According to Euromonitor (2014), the Chinese food service sector is the largest worldwide with 7.3 million outlets and sales valued at US\$ 510 billion in 2013. In the food services sector two international companies are at the top of the list (Figure 12.9): McDonald's and Yum! The first is the largest chain of hamburger fast food restaurants in the world, founded in the United States in 1940. The American company is adopting a new business model in Asian countries using larger franchising models. Yum! Brands, Inc. (previously Tricon Global Restaurants, Inc.) is a US fast food company. It includes very well known brands such as KFC, Pizza Hut and in May 2011, Yum! agreed to purchase the mainland Chinese hot-pot chain, Little Sheep. This company, even though its sales on the international market are about half those of McDonald's, holds first place in the Chinese market with a turnover more than twice that of McDonald's.

In relation to food retailing, there are a number of different types of marketing strategies used in China (Table 12.1). ${ }^{6}$ Euromonitor (2014) and official statistics show supermarkets/hypermarkets are now dominating the retail landscape, with a market share of around $50 \%$.

Even if modern forms of retailing are growing, Chinese agricultural produce is predominantly purchased directly from farmers (Ren, 2008), often just after harvest and on the roadside, by hundreds of thousands of private traders who cruise villages

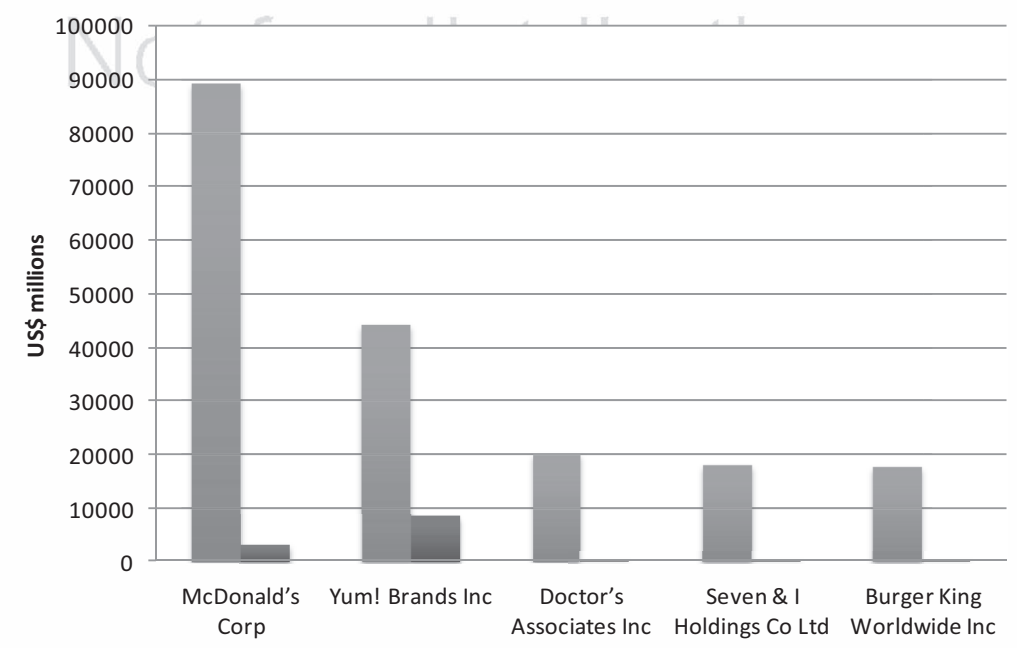

International Foodservice Sales Foodservice Sales in China

Figure 12.9 Top 5 Foodservice Companies Worldwide, US\$ Millions (2013)ì

Source: Authors' elaboration on Euromonitor International, 2014 
Table 12.1 The Structure of China's food distribution network

\begin{tabular}{lllllllllll}
\hline & 2003 & 2004 & 2005 & 2006 & 2007 & 2008 & 2009 & 2010 & 2011 & $\begin{array}{l}\text { \% of } \\
\text { growth } \\
2003- \\
2011\end{array}$ \\
\hline $\begin{array}{l}\text { Restaurants/fast } \\
\text { food/eat-out } \\
\text { stores }\end{array}$ & 5000 & 6500 & 9000 & 11000 & 12000 & 12000 & 13000 & 14000 & 15000 & 200.0 \\
$\begin{array}{c}\text { Supermarkets/ } \\
\text { hypermarkets }\end{array}$ & 16000 & 16500 & 22000 & 24000 & 35000 & 33000 & 38000 & 40000 & 42000 & 162.5 \\
$\begin{array}{c}\text { Convenience } \\
\text { stores }\end{array}$ & 4500 & 8000 & 9500 & 13000 & 13500 & 18000 & 13000 & 14000 & 14000 & 211.1 \\
\begin{tabular}{c} 
Total \\
\hline
\end{tabular} & $\mathbf{2 5 5 0 0}$ & $\mathbf{3 1 0 0 0}$ & $\mathbf{4 0 5 0 0}$ & $\mathbf{4 8 0 0 0}$ & $\mathbf{6 0 5 0 0}$ & $\mathbf{6 3 0 0 0}$ & $\mathbf{6 4 0 0 0}$ & $\mathbf{6 8 0 0 0}$ & $\mathbf{7 1 0 0 0}$ & $\mathbf{1 7 8 . 4}$ \\
\hline
\end{tabular}

Source: Authors' elaboration on data from EUSME, The Food \& Beverage Market in China, 2015

Table 12.2 Ownership structure of food and beverage wholesale industry in China in 2011

\begin{tabular}{lcc}
\hline & Number of enterprises & Annual sales (100 mn RMB) \\
\hline Privately owned & 26000 & 22500 \\
Collective/JV owned & 8700 & 13300 \\
Foreing owned & 4900 & 14600 \\
State-owned enterprises & 1500 & 4600 \\
\hline
\end{tabular}

Source: Authors' elaboration on data from ANZ, Chinese National Bureau of Statistics

and the surrounding countryside in small trucks. State-owned enterprises no longer monopolize the wholesale (processing/marketing/distribution) part of the supply chain (Table 12.2). This has resulted in a diversified ownership structure of the industry and increased competition. Private enterprises in 2011 now constitute $63 \%$ of wholesale companies, but only $41 \%$ of annual sales. The popularity of private small-sized wholesalers in the industry is likely to constrain further development.

\section{Consumption}

In 1990 food expenditure (total consumption expenditure index=100) was 54.2\% of the total per capita consumption expenditure in urban areas and $58.8 \%$ in rural areas (China Statistical Yearbook, 2014). The indices have been decreasing over time and disposable income spent on food in 2013 averaged around 35\% for urban households and 38\% for rural households (Figure 12.10).

As Engel's law suggests, there is a wide range of different types of consumers, depending on income levels. The wealthiest $20 \%$ of urban households $(10 \%$ of all Chinese households) spend less than $22 \%$ of their disposable income on food. On the other hand, the poorest $10 \%$ of urban households (accounting for $5 \%$ of all Chinese households) spend more than $40 \%$ of their disposable income on food, and $66 \%$ in the case of their rural counterparts (ANZ, 2013). 


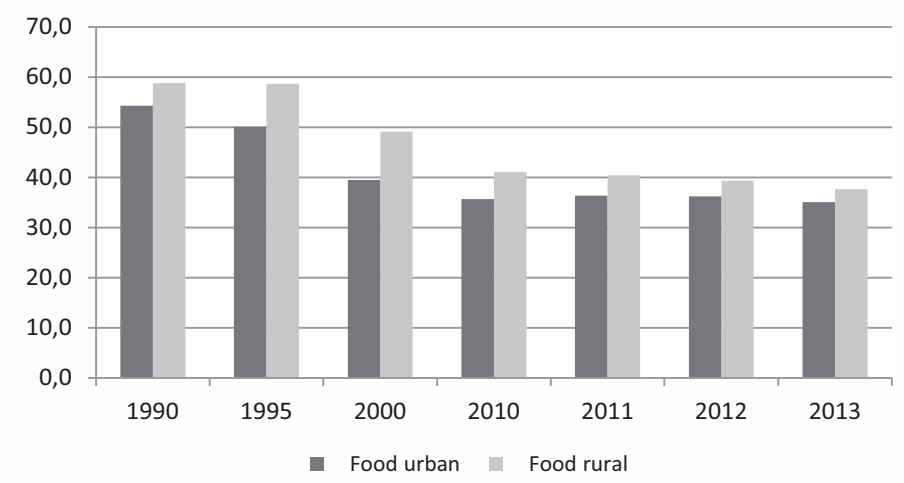

Figure 12.10 Food Consumption Expenditure per capita (index=100): Urban and rural households in China

Source: Authors' elaboration on China Statistical Yearbook, 2014

Some changes have been occurring in consumption habits: in urban areas expenditure on clothing, the second most important item after food in the 1990s (equal to 13\%), has been surpassed by 'transport and communications' (15.2\% in 2013) and 'education, culture and recreation' (12.7\% in 2013). In rural areas, instead, housing expenditure is confirmed in 2013 as the second highest expenditure after food (15\% and 19\%), followed by 'transport and communications' $(12 \%$ in 2013) and 'health care' (7\% in 2013). People's consumption habits are mainly connected to rising disposable incomes: per capita income in urban areas went from 1,500 yuan in 1990 to 30,000 yuan in 2013 and in rural areas from 700 yuan in 1990 to 9,000 yuan in 2013 (Figures 12.13 and 12.14). It is worth noting that in 2012 the ratio between per capita income in rural areas and that in urban areas decreased, passing from about a half to one third. Analyzing data (China Statistical Yearbook, 2014) concerning consumption expenditure on goods and services, ${ }^{7}$ a different trend in rural and urban households is detected. ${ }^{8}$

Differences in consumption habits can be observed when comparing urban and rural areas; rich and poor consumers; and the population of different regions. In rural areas meat consumption per head is lower and lags behind that of urban residents by about 30 years (the consumption by rural residents in 2010 was equal to that of urban residents in 1982). High income residents consumed more of all food types compared with poorer people, with two exceptions: food grains and Chinese liquor (Cao et al., 2013).

In addition to income levels, urbanization, brand exposure and consumer affluence, food safety concerns, health consciousness, demand for convenience, improved infrastructure and the development of the retail industry, which are other aspects that affect consumption patterns, changed significantly with improved standards of living. More consumers are exposed to a greater diversity of consumer products, both locally and when travelling abroad. Chinese consumers are 
increasingly discerning, and many now seek the following qualities when making purchases: confidence in food safety and the integrity of ingredients; high quality; excellent nutritional value; a better lifestyle through the variety of food and beverages; modern packaging; freshness and convenience.

If the rate of food expenditure tends to decrease as income rises, food expenditure in absolute terms has risen sharply: for urban households from nearly 694 in 1990 to 6,311 yuan in 2013, and for rural households from 156 in 1990 to 2,054 yuan in 2013 (Figures 12.11 and 12.12).

Food expenditure per capita, urban households

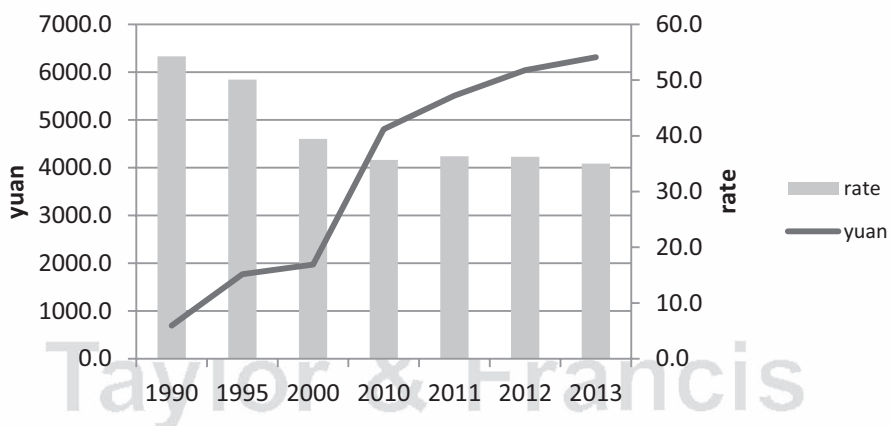

Figure 12.11 Food expenditure per capita (yuan and rate of total consumption) in urban households in China

Source: Authors' elaboration on China Statistical Yearbook, 2014

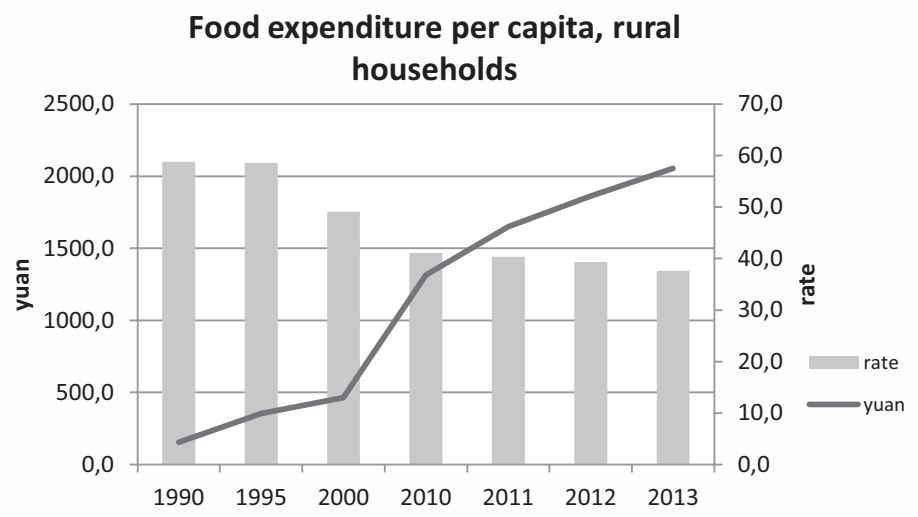

Figure 12.12 Food expenditure per capita (yuan and rate of total consumption) in rural households in China

Source: Authors' elaboration on China Statistical Yearbook, 2014 
In the evolution of consumer patterns, three periods can be identified. In the first period (1990-2000), food expenses in absolute values (increasing) and as a percentage of total consumption expenditure (decreasing) move in the opposite direction, with equal magnitude and is more pronounced in urban areas. The index, which in 1990 amounted to $54.2 \%$, decreases to $39.4 \%$ in 2000 for urban households and, in rural areas, from $59 \%$ to $49 \%$.

The decade 2000-2010 represents a period of great growth in food expenditure. For urban households it increased from 1,971 yuan in 2000 to 4,804 yuan and for rural from 464 to 1,313 yuan with, however, decreasing index movements. ${ }^{9}$ In the period (2010-2013), the indices show a relative stability in urban areas, while decreasing most significantly in rural households against an increase in absolute values.

\subsection{Trade}

The importance of agricultural trade to China's total trade, has been declining since 1980 and particularly since the early 1990s due to the decreasing trend of agriculture in China's economy (Huang et al., 2007). Since China joined the World Trade Organization in late 2001, agricultural exports to the country have grown exponentially (WTO, 2015). Until the middle of the first decade of the 2000s, the balance of Chinese food trade was positive and China was a net food exporter country (Table 12.3).

In 2008 China's food trade deficit began and it gradually widened and reached US\$ 41.8 million in 2014. China imports food from 192 countries and regions.

At a global level, among the top ten importers of agri-food and seafood, China ranks second, after the United States. It can be observed (Table 12.4) that the exchange between European countries is carried out mainly between EU countries (as a consequence of a well-established feature of the Common Agricultural Policy), while trade in other countries appears more diversified.

Currently, achieving Market Economy Status (MES) at the WTO is one of China's core strategic goals. As expected, the recognition of China as a market economy is hampered by the EU (southern European countries especially) and the US, worried about having to face competition based on lower costs of production. Moreover, according to the WTO, China still applies price controls on commodities and services with a direct impact on the domestic economy and people's livelihoods. As a consequence, China has launched a legal challenge against the EU and US.

Furthermore, there are concerns in the food trade regarding trade between China and the EU, arising from the legal protection of geographical indication (GI) products (European Commission, 2013) being continuously a source of conflicts. To better protect these products, the EU signed various multilateral and bilateral agreements. Among these initiatives, it is worthwhile mentioning the ' 10 plus 10' project (European Commission, 2012) started in July 2007 when both the EU and China formally lodged' applications for the protection of 10 agriculture 
Table 12.3 China's food trade 1980-2014 (US\$ millions)

\begin{tabular}{lrrr}
\hline \multicolumn{3}{l}{ China's food trade } & \\
\cline { 2 - 4 } & Imports & Exports & $\begin{array}{c}\text { Trade balance } \\
\text { (exports-imports) }\end{array}$ \\
\hline 1980 & $3,206.3$ & $3,128.9$ & -77.4 \\
1985 & $1,755.6$ & $4,274.7$ & $2,519.1$ \\
1990 & $4,618.7$ & $7,867.5$ & $3,248.8$ \\
1995 & $9,236.4$ & $12,299.1$ & $3,062.7$ \\
2000 & $9,042.6$ & $13,559.3$ & $4,516.8$ \\
2001 & $9,366.2$ & $14,222.1$ & $4,855.9$ \\
2002 & $9,891.2$ & $16,163.5$ & $6,272.4$ \\
2003 & $14,970.5$ & $19,241.8$ & $4,271.3$ \\
2004 & $21,121.1$ & $20,815.2$ & -306.0 \\
2005 & $21,540.7$ & $24,635.4$ & $3,094.6$ \\
2006 & $22,917.3$ & $27,862.6$ & $4,945.4$ \\
2007 & $32,422.3$ & $33,160.8$ & 738.5 \\
2008 & $49,521.7$ & $35,887.5$ & $-13,634.2$ \\
2009 & $45,248.4$ & $35,318.6$ & $-9,929.8$ \\
2010 & $59,556.2$ & $44,152.5$ & $-15,403.7$ \\
2011 & $75,455.2$ & $54,167.8$ & $-21,287.4$ \\
2012 & $90,650.4$ & $56,311.9$ & $-34,338.5$ \\
2013 & $98,646.3$ & $59,977.6$ & $-38,668.7$ \\
2014 & $105,263.6$ & $63,490.9$ & $-41,772.7$ \\
\hline
\end{tabular}

Source: Authors' elaboration on WTO data, 2014

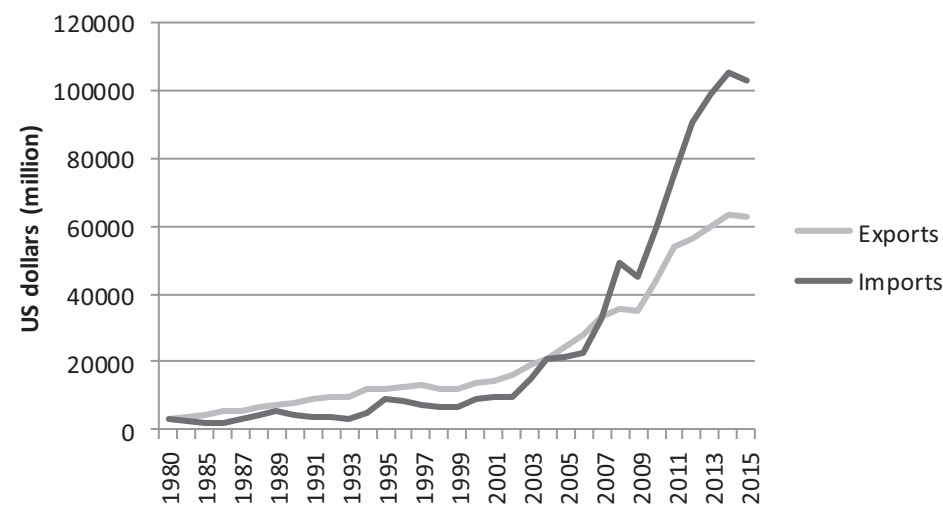

Figure 12.13 China's food imports and exports (1980-2014)

Source: Authors' elaboration on WTO data 
Table 12.4 Top 10 Agri-food and seafood importers Worldwide, 2013

\begin{tabular}{lllll}
\hline Country & $\begin{array}{l}\text { Imports } \\
\text { billions }\end{array}$ & \multicolumn{2}{l}{ Top suppliers and market share } & \\
\cline { 3 - 5 } & & & 2 & 3 \\
\hline United States & 127.4 & Canada & Mexico & China \\
China & 118.0 & United States $(22.6 \%)$ & Brazil (19.1\%) & Australia (7.3\%) \\
Germany & 106.8 & Netherlands & France & Italy \\
Japan & 76.5 & US & China & Canada \\
Netherlands & 71.5 & Germany & Belgium & Brazil \\
United Kingdom & 68.8 & Netherlands & France & Ireland \\
France & 64.9 & Spain & Netherlands & Belgium \\
Italy & 54.8 & Germany & France & Spain \\
Belgium & 42.0 & Netherlands & France & Germany \\
Russia & 39.7 & Brazil & Germany & Ukraine \\
\hline
\end{tabular}

Source: Authors' elaboration on Euromonitor International, 2014

GI products in each other's territories (Tables 12.5a and12.5b). The European list contains five cheeses, two olive oils, one ham, 1one salmon and 1one dried fruit. In terms of countries, France and the UK have three products each, while Italy and Spain have two. In parallel, the European Commission has examined and registered 10 Chinese food names with the last two Chinese names 'Pinggu da Tao' (peach) and 'Dongshan Bai Lu Sun' (asparagus) receiving protected status in the EU as geographical indication products (European Commission, 2013).

These 10 Chinese names have been added to the more than 1,000 names of agricultural products and foodstuffs, which are already protected in the EU.

\section{Agricultural policies in a nutshell}

A historical overview of China highlights the high importance given to agriculture by Chinese policymakers since the proclamation of the People's Republic of China in 1949. In this Chapter, only some aspects of the Chinese policy will be taken into consideration.

Being self-sufficient to meet domestic demand for cereals and avoid having to resort to massive imports has always been the main concern of the government.

On 28 June 1950 Liu Shaoqi (刘少奇) implemented the first agricultural reform (土改, tǔgăi), called 'land to the tiller' (耕者有其田 gèngzhěyǒuqitián) addressed to all the non-farmland owning farmers (about $70 \%$ of the 500 million people in the countryside). It increased the fragmentation of agricultural land and lead to the consequent difficulty of extensive cultivation. Just three years after this land reform, the plan for collectivization of land, aimed at setting up a new production structure based on collectively owned companies, was adopted. Land ownership passed to communities, and farmers were forced to sell to the State surplus wheat production at prices and quantities set by the government (Lin, 1992).

The new Chinese countryside arrangement (in 1956, 90\% of farmers were enrolled in socialist cooperatives) seemed to give new impetus to agricultural 
Table 12.5a Ten renowned European products registered in the official AQSIQ* Chinese GI register

\begin{tabular}{lll}
\hline Country & $\begin{array}{l}\text { Number of } \\
\text { products } \\
\text { registered }\end{array}$ & Designation (and type of product) \\
\hline France & 3 & $\begin{array}{c}\text { Comté (cheese); Pruneaux d'Agen/Pruneaux d'Agen } \\
\text { mi-cuits (dried fruits); Roquefort (cheese); } \\
\text { Scottish Farmed Salmon (fish); West Country Farmhouse } \\
\text { Cheddar (cheese); White Stilton Cheese/Blue Stilton } \\
\text { Cheese (cheese) }\end{array}$ \\
$\begin{array}{l}\text { United } \\
\text { Kingdom }\end{array}$ & 3 & $\begin{array}{l}\text { Grana Padano (cheese); Prosciutto di Parma (ham); } \\
\text { Priego de Córdoba (oil); Sierra Mágina (oil) }\end{array}$ \\
Itay & 2 & 2
\end{tabular}

*General Administration of Quality Supervision, Inspection and Quarantine of the People's Republic of China

Source: Authors' elaboration on European Commission, 2013

Table $12.5 b$ Ten renowned Chinese products protected in the EU

\begin{tabular}{ll}
\hline Type of product & Designation \\
\hline Fruits & $\begin{array}{c}\text { Pinggu Da Tao (peach); Guanxi Mi You (honey pomelo); Shaanxi } \\
\text { ping guo (apple); }\end{array}$ \\
Vegetables & $\begin{array}{l}\text { Dongshan Bai Lu Sun (Asparagus); Jinxiang Da Suan (garlic); } \\
\text { Fish/meat }\end{array}$ \\
$\begin{array}{l}\text { Yancheng Long Xia (Crayfish);Lixian Ma Shan Yao (ham) } \\
\text { Other }\end{array}$ & Zhenjiang Xiang Cu (rice vinegar); Longjing cha (tea); Longkou \\
& Fen Si (noodles) \\
\hline
\end{tabular}

Source: Authors' elaboration on European Commission, 2013

production which recorded an annual increase of 3.5\% (compared with the level of production in 1952) in cereals thanks to the adoption of the 'grain first' policy (以粮为纲, yùliángwèigāng) (Zanier, 2010).

After the first five-year plan (五年计划, wǔniánjihuà), the Chinese leadership began a new strategy, known as the 'Great Leap Forward' (大跃进, dàyuèjinn). The object was to 'produce more, more quickly and at a better price' (Bergère, 2000: 110) to allow China within 15 years to overtake the United Kingdom (赶上 英国十五年, gănshàngyīngguóshìwǔnián). However, agricultural production, in 1960, reached only 144 million tons, down $26.4 \%$ compared to 1958 . This failure was due to a combination of factors: the shift in labor force from agriculture to the steel industry and to the construction of great hydraulic works, the 'Four pests campaign' that led to the extermination of sparrows and to the spread of insects and different pests, and a series of natural disasters that swept China in the late 1950 s. ${ }^{10}$ Only in 1965 , was there a resumption of production to levels achieved before the Great Leap Forward (Bergère, 2000). The decline in production was compounded by the diffusion of distorted statistics which were used to decide the amount of grain to be exported in the period between 1958 and 1960, jeopardizing the self-sufficiency of the country. In 1960 the shortage turned into famine and the 
per capita consumption of cereals fell by $23.7 \%$, going from $204 \mathrm{~kg}$ in 1957 to 156 $\mathrm{kg}$ in 1960 (Bergère, 2000) causing millions of deaths (Brown, 1995).

In 1978, a new era of reform began, with economic liberalization implemented by Deng Xiaoping (邓小平) after the death of the leader, Mao Zedong (毛泽东). Two major new features were introduced: the household responsibility system and township and village enterprises (OECD, FAO, 2013). Thanks to the first of these features, between 1981 and 1982, about $90 \%$ of farm families became responsible for a plot of land, which was previously publicly owned but was leased to families for longer and longer periods of time (Zanier, 2010). The second innovation, known by the acronym TVE or Township and Village Enterprises (乡镇企业, xiāngzhènqiyè), led to a significant increase in agricultural production, so that China returned to exporting cereals and agricultural income tripled between 1979 and 1985.

At the beginning of the 1990s China entered international markets: in 19931994 the country's exports increased by $60 \%$, and the amount of foreign investments were greater than in all fourteen previous years (Zanier, 2010). The entry into the WTO in 2001 and the abolition of import duties significantly increased imports of agricultural goods (Fuller et al., 2001; Sun, 2016). As previously mentioned, in 2008 China became a net food importer (Cao et al., 2013).

In 2006, an agricultural tax that had been levied for millennia was abolished, bringing savings to farmers of over US\$ 21 billion (Ni, 2013). As well as eliminating taxes, over the years the government has allocated an increasing share of its financial resources to agricultural subsidies. The following are the four main typologies of subsidies:

1 Grants for the improvement of seeds (良种补贴, liángzhóngbǔtiē). These are in place since 2002 to promote the use of new and improved varieties of cultures, accelerating their use and, since 2009, they have been extended to the whole country with regards to rice, wheat, cotton and corn (Ni, 2013).

2 Direct payments to producers of cereals (粮食直补, liángshizhíbǔ). This policy was adopted in 2004 with the aim of reversing the drop in cereal production registered during the previous six years. The stated objective of this measure is to increase the production of cereals, promoting self-sufficiency in the country.

3 Subsidies for the purchase of agricultural machinery (购置补贴, gòuzhibǔtiē). The objective is to promote the mechanization of agriculture so as to increase productivity. The stated goal is to achieve $70 \%$ mechanization of farming methods (DuPont, 2013).

4 Generic grants to inputs (农资综合补贴, nóngzīzònghébǔtiē). This measure was adopted starting in 2006 because of continuing fluctuations in prices of agricultural inputs including fertilizers and gasoline.

Immediately after entering the WTO, the Chinese authorities started to strengthen the policy of supporting market prices to sustain the income of farmers and encourage production. This policy, however, has triggered rising home market 
prices that, combined with the appreciation of the Chinese currency, have eroded the competitiveness of Chinese agricultural goods on the international market (OECD, FAO, 2013). A second effect was the increase in imports of foreign products available at lower prices and therefore more competitive with Chinese produce. Although China is expected to become the world's largest producer of rice and wheat, and occupies second place in world production of corn and buckwheat, the export of cereals (including barley, corn, millet, rice, rye, oats, sorghum, wheat and cereal blends) has gradually decreased from 19 million tons in 2002 to only 1.5 million in 2013.

Thanks to the extensive program of reforms initiated by the government during the decade 2004-2014, grain production has recorded steady growth year after year, enabling the country to achieve the so-called 'Grain Miracle' (Zhang, 2013). Production has increased by $29 \%$ from 469 million tons in 2004 to 607 million in 2014.

Recently, the National Development Plan for the period 2011-2015, the most recent plan (issued in March 2011), has policies to boost domestic consumption, improve living standards, develop the western and central regions and protect the environment. ${ }^{11}$

With regards to the food industry, the plan points out food safety as a main concern. With many food safety scandals in the past few years, the government has included policies to address this issue. The overall focus is on improving agricultural production and attracting foreign technology.

\section{Main constraints}

According to Aquastat (2014), China has renewable internal freshwater resources of about 2,000 cubic meters per capita, above the UN definition of water scarcity of 1,000 cubic meters per person (Figure 12.14).

China's water resources are not distributed equally: the dry northern and western desert provinces receive only $20 \%$ of the country's rainfall. In addition, due to inevitable population growth, climate change, increasing urbanization and the many activities that require water resources, per capita availability is continuously decreasing and demand for water is outstripping supply. As a result, in urban areas the share of population with access to safe drinking water is decreasing (Figure 12.15).

Agriculture and energy (mainly the coal industry) are the two largest consumers of China's freshwater reserves (Figure 12.16), accounting for nearly $90 \%$ of all the water used in China).

Agriculture and the coal industry are concentrated in China's North, where the average water per capita availability is only around 200 cubic meters. Therefore, although four-fifths of the country's water resources are located in the South of the country, two-thirds of the cultivated land is in the arid North (Hanjira et al., 2008). To solve this unequal distribution, since 2002 China has been working on a mega-project to bring water from the moisture-rich South to the arid North. Nevertheless, simply supplying more water will not solve the underlying problems. 


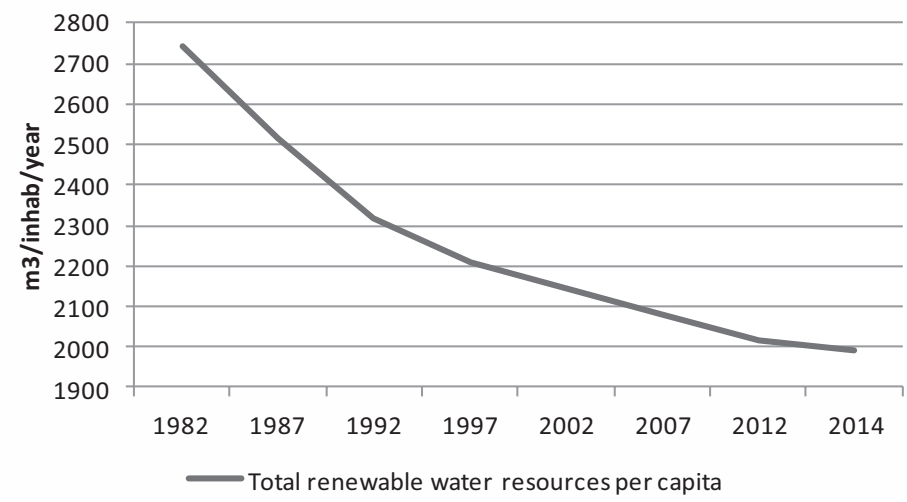

Figure 12.14 Total renewable water resources per capita

Source: Authors' elaboration on Aquastat data, 2014

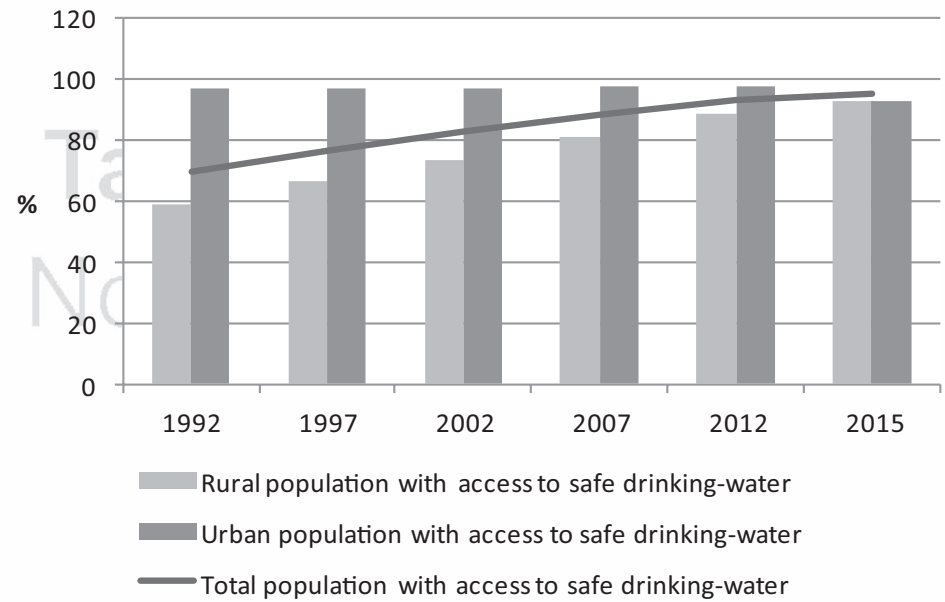

Figure 12.15 Population with access to safe drinking water

Source: Authors' elaboration on Aquastat data, 2014

In 2010, China's Communist Party Central Committee and State Council promulgated a 'Three Red Lines'12 (santiao hongxian 三条红线) policy intended to establish clear and binding limits on water usage, efficiency, and quality. In early 2012, the State Council announced that the 'Three Red Lines' policy would limit total national water consumption to less than 700 billion $\mathrm{m}^{3}$ per year, amounting to approximately three-quarters of China's total annual exploitable freshwater resources. In addition, the policy attempts to increase irrigation use efficiency. ${ }^{13}$ The People's Republic of China's (PRC) 12th Five-Year Plan (2011-2015) 


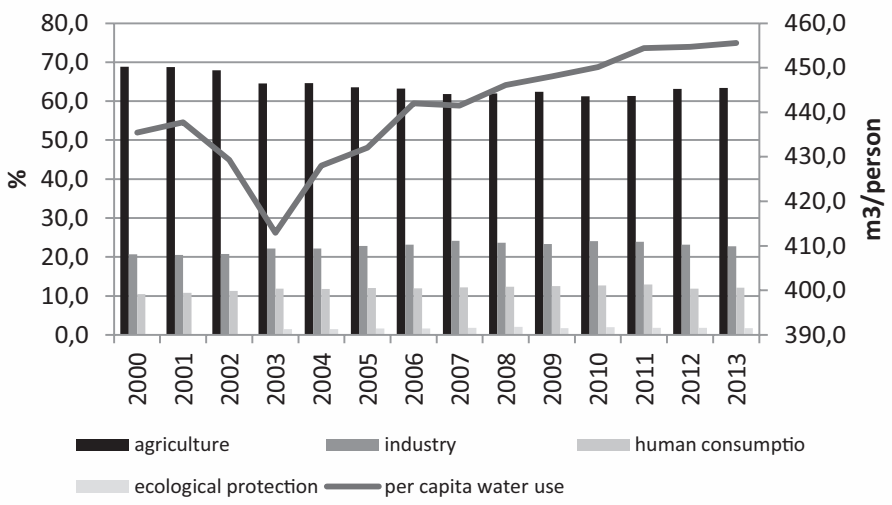

Figure 12.16 Water use

Source: Authors' elaboration on Chinese Statistical yearbook, 2014

focuses on water conservation and environmental protection as national priorities. China's leadership acknowledges in this plan that there is much to be done to limit pollution and secure adequate supplies of energy and water for growing northern and western cities. China's major cities, for example, are retrofitting their sewage treatment systems to recycle wastewater for use in washing clothes, flushing toilets, and other grey-water applications. Major industrial plants are required by the Water Law, initially enacted in 1988 and updated in 2002, to show that there is adequate water in the region to supply new factories before they are allowed to build (Circle of Blue, 2013).

Soil pollution is another crucial issue and a possible constraint on agriculture and food supply.

According to Cui and Kattumuri (2011), a study on soil pollution commissioned in 2006 by the government shows that industrial and urban effluent and waste as well as the massive use of fertilizers and pesticides have affected about one-fifth of Chinese agricultural land and have caused a loss of about 10 billion $\mathrm{kg} /$ year of crops. This loss becomes even more important considering that arable land is steadily decreasing.

Climate change can also play a critical role in determining the country's ability to maintain the viability of agricultural production. The frequency and intensity of adverse weather events, such as droughts in the North and Northeast and floods along the Yangtze river, have increased in the last fifty years as well as the relentless advance of desertification that affects about 666,700 hectares, of which about 200,000 hectares are arable land (Cui and Kattumuri, 2011).

Aware of these constraints, China, since the first decade of the 2000 s, has progressively tried a new and alternative way to achieve a secure source of food supply by resorting to outward foreign direct investment (FDI) in agriculture (Smaller et al., 2012). Since 2001, the FDI flow in agriculture has gradually 
increased US\$ 5 billion in 2012). Since 2007 foreign investment in the primary sector has often taken the form of the so-called 'land grabbing': acquisitions (by purchase or rental) of large-scale land for farming, conducted by public actors (States) or private (companies) that usually have an average duration of 30 to 99 years (Zolin and Luzi, 2013).

In relation to China as an outward investor country, according to the Land Matrix, total Chinese land investment amounted to more than 1.206 million hectares with 65 agreements signed from 2001 to 2014 (Table 12.6). ${ }^{14}$ More than 414,000 hectares (34\% of the total) are domestic investments within national borders. Approximately 792,000 hectares are concentrated in some favorite target

Table 12.6 China's land investments (2014)

\begin{tabular}{|c|c|c|c|c|}
\hline $\begin{array}{l}\text { Target } \\
\text { countries }\end{array}$ & $\begin{array}{l}\text { Number of } \\
\text { contracts } \\
\text { signed }\end{array}$ & $\begin{array}{l}\text { Investment } \\
\text { on land in } \\
\text { ha (contracts } \\
\text { signed only) }\end{array}$ & $\begin{array}{l}\text { Average } \\
\text { size of } \\
\text { investments } \\
\text { (in ha) }\end{array}$ & Purpose of investments \\
\hline Asia & 43 & 695,089 & 16,165 & \\
\hline Cambodia & 19 & 192,706 & 10,142 & $\begin{array}{l}\text { Non food agricultural } \\
\text { commodities (11), Food crops } \\
\text { (3), Agri unspecified (3), } \\
\text { Wood and fibre (1), Tourism (1) }\end{array}$ \\
\hline China & 8 & 414,054 & 51,757 & Food crops (7), other (1) \\
\hline Laos & 15 & 48,329 & 3,222 & $\begin{array}{l}\text { Non food agricultural } \\
\quad \text { commodities (12), Industry (2) } \\
\text { Wood and fibre (1) }\end{array}$ \\
\hline Philippines & 1 & 40,000 & 40,000 & Biofuels \\
\hline Africa & 18 & 163,704 & 9,095 & \\
\hline Angola & 3 & 21,500 & 7,167 & Food crops (3) \\
\hline Benin & 2 & 4,800 & 2,400 & Biofuels, food crops \\
\hline Cameron & 1 & 10,120 & 10,120 & Food crops \\
\hline Congo & 1 & 100,000 & 100,000 & Biofuels \\
\hline Nigeria & 2 & 5,300 & 2,650 & Food crops \\
\hline Sierra Leone & 4 & 6,820 & 1,705 & Food crops (4) \\
\hline Sudan & 1 & 10,000 & 10,000 & Biofuels, food crops \\
\hline Uganda & 2 & 4,540 & 2,270 & Food crops $(2)$ \\
\hline Tanzania & 2 & 624 & 312 & $\begin{array}{l}\text { Food crops, biofuels, wood and } \\
\text { fibre }\end{array}$ \\
\hline Europe & 1 & 2,000 & 2,000 & \\
\hline Bulgaria & 1 & 2,000 & 2,000 & Food crops \\
\hline $\begin{array}{l}\text { South } \\
\text { America }\end{array}$ & 3 & 345,400 & 115,133 & \\
\hline Argentina & 2 & 333,000 & 166,500 & Food crops \\
\hline Bolivia & 1 & 12,400 & 12,400 & Food crops \\
\hline Total & 65 & $1,206,193$ & 5,123 & - \\
\hline
\end{tabular}

Source: Authors' elaboration on Land Matrix data, 2015 
areas: Asia occupies first place (57.6\% of total), followed by Latin America (28.6\% of total) and Africa ( $13.6 \%$ of total).

The deal gives the investor not only the right to cultivate the land, but also gives access to natural resources, water and minerals. Establishing the precise number of agreements signed is not simple. These contracts, are often negotiated with local governments for the use of land under concession for a length of time, followed by the deployment of one or more production sites. For the Chinese side, that should ensure a transfer of technical knowledge - with benefits for local people (especially in the poorest countries) - having the ability to export 'strategic' agricultural products to China at favorable prices. Although in theory local people should benefit from this Chinese presence, there have been numerous protests: Chinese companies are in fact accused of appropriating the land of poor local farmers, who, once dispossessed of their belongings, would not have the chance to be taken on as employees in the new Chinese factories that only employ Chinese labor.

The 'Chinese colonization' involves not only land, but also the acquisition of large foreign agribusiness empires: the so-called 'dragon-head' enterprises, (龙头企业, lóngtóuqǐyè) are in fact encouraged to expand their global presence through acquisitions of companies in key areas of the world food industry, thus challenging the hegemony of the great American groups such as Cargill, sand

\section{Concluding remarks}

China is the world's largest consumer market for food and beverages but is also a net importer of food. If the rate of food expenditure tends to decrease as income goes up, food expenditure in absolute values increases: in the period 2000-2010, it increased from 2,000 yen per capita in 2000, to almost 5,000 in 2010 for urban consumers. In the long term, China's demand for food imports will inevitably grow (Cao et al., 2013). The Chinese food industry is profiting from this development, but China is thus facing problems relating both to food security and to food safety.

As far as food security is concerned, the biggest advances in China's productivity, resulting from an (often excessive) application of fertilizer, has polluted land and groundwater with nitrates and caused toxic 'red tides' of algal blooms and the eutrophication of lakes and rivers. ${ }^{15}$ Moreover, Chinese agricultural productivity is affected by the scarcity of natural resources (land and water) and the supply of arable land is not adequate to meet Chinese food security. To counteract land limitation, China has progressively tried a new and alternative way to find a secure supply by resorting to outward foreign direct investment (FDI) in agriculture. Asian countries are the favorite target of this new policy: the acquisitions, not only gives the investor the right to cultivate the land, but also gives access to natural resources, water and minerals. Conflict with local populations are increasing as they identify these investments as a violation of human rights. 
Climate change can also play a crucial role in determining the country's ability to reach self-sufficiency.

Meanwhile, two growing food safety concerns are illegal additives to food and contamination by toxic industrial waste. China's connections to global agricultural markets are also having important effects on food supply and food safety within the country. Although the Chinese government has shown determination to reform laws, establish monitoring systems, and strengthen food safety regulation, weak links in implementation remain.

As a global problem, food safety affects public health, especially in countries with large populations, e.g. China. A 2011 survey (Zhang, 2013) reported that food safety was the most pressing issue for Chinese people, surpassing public security, traffic safety, medical safety, etc. Food contamination can occur at any step in the process from farm to table. ${ }^{16}$ In addition, with rapid Chinese industrialization, the use of illegal additives and toxic industrial waste in food processing is a growing food safety problem.

Resourcefulness, technology, research, modernization, and sustainability are all factors, which China can and should focus on, as they will have a key role in determining the ability of China and of the world to feed their respective populations with safe food in the future.

Improved efficiency and productivity, the reform of land use rights, but also the policy of 'going out' or land investments are some of the plausible strategies that the country could improve on to avoid an inexorable stabilization or, at worst, a decline in domestic production, as well as taking into account the impact of climate change on agricultural commodities.

The Chinese food industry, on the one hand, is driven by the changing consumption habits of the Chinese population and favored by the market economy, which provides a huge platform for future development; while-on the other hand, it needs technological innovation and research, development investments and the enforcement of safety measures. 


\section{Appendix}

Table A Per capita income and expenditure of urban households

\begin{tabular}{|c|c|c|c|c|c|c|c|}
\hline & 1990 & 1995 & 2000 & 2010 & 2011 & 2012 & 2013 \\
\hline $\begin{array}{l}\text { Per Capita Annual } \\
\text { Income* (yuan) }\end{array}$ & $1,516.2$ & $4,288.1$ & $6,295.9$ & $21,033.4$ & $23,979.2$ & $26,959.0$ & $29,547.1$ \\
\hline $\begin{array}{l}\text { Per Capita Annual } \\
\text { Consumption** } \\
\text { (yuan) }\end{array}$ & $1,278.9$ & $3,537.6$ & 4,998.0 & 13471.5 & $15,160.9$ & $16,674.3$ & $18,022.6$ \\
\hline \multicolumn{8}{|l|}{ Of which: } \\
\hline Food & 693.8 & $1,772.0$ & $1,971.3$ & $4,804.7$ & $5,506.3$ & $6,040.9$ & $6,311.9$ \\
\hline Clothing & 170.9 & 479.2 & 500.5 & $1,444.3$ & $1,674.7$ & $1,823.4$ & $1,902.0$ \\
\hline Residence & 60.9 & 283.8 & 565.3 & $1,332.1$ & $1,405.0$ & $1,484.3$ & $1,745.1$ \\
\hline $\begin{array}{l}\text { Household Facilities } \\
\text { and Articles }\end{array}$ & 108.5 & 263.4 & 374.5 & 908.0 & $1,023.2$ & $1,116.1$ & $1,215.1$ \\
\hline $\begin{array}{l}\text { Transport and } \\
\text { Communications }\end{array}$ & 40.5 & 183.2 & 427.0 & $1,983.7$ & $2,149.7$ & $2,455.5$ & $2,736.9$ \\
\hline $\begin{array}{l}\text { Education, Culture } \\
\text { and Recreation }\end{array}$ & 112.3 & 331.0 & 669.6 & $1,627.6$ & $1,851.7$ & $2,033.5$ & $2,294.0$ \\
\hline $\begin{array}{l}\text { Health Care and } \\
\text { Medical Services }\end{array}$ & 25.7 & 110.1 & 318.1 & 871.8 & 969.0 & $1,063.7$ & $1,118.3$ \\
\hline Others & 66.6 & 114.9 & 171.8 & 499.2 & 581.3 & 657.1 & 699.4 \\
\hline \multicolumn{8}{|l|}{$\begin{array}{l}\text { Consumption } \\
\text { Expenditure } \\
\text { index }=100\end{array}$} \\
\hline Food & 54.2 & 50.1 & 39.4 & 35.7 & 36.3 & 36.2 & 35.0 \\
\hline Clothing & 13.4 & 13.5 & 10.0 & 10.7 & 11.0 & 10.9 & 10.6 \\
\hline Residence & 4.8 & 8.0 & 11.3 & 9.9 & 9.3 & 8.9 & 9.7 \\
\hline $\begin{array}{l}\text { Household Facilities } \\
\text { and Articles }\end{array}$ & 8.5 & 7.4 & 7.5 & 6.7 & 6.7 & 6.7 & 6.7 \\
\hline $\begin{array}{l}\text { Transport and } \\
\text { Communications }\end{array}$ & 3.2 & 5.2 & 8.5 & 14.7 & 14.2 & 14.7 & 15.2 \\
\hline $\begin{array}{l}\text { Education, Culture } \\
\text { and Recreation }\end{array}$ & 8.8 & 9.4 & 13.4 & 12.1 & 12.2 & 12.2 & 12.7 \\
\hline $\begin{array}{l}\text { Health Care and } \\
\text { Medical Services }\end{array}$ & 2.0 & 3.1 & 6.4 & 6.5 & 6.4 & 6.4 & 6.2 \\
\hline Others & 5.2 & 3.2 & 3.4 & 3.7 & 3.8 & 3.9 & 3.9 \\
\hline
\end{tabular}

* Per capita income measures the average income earned per person in a given area (city, region, country, etc.) in a specified year. It is calculated by dividing the area's total income by its total population

** Per capita consumption expenditure is the market value of all goods and services, including durable products (such as cars, washing machines, and home computers), purchased by households. It is calculated by dividing the area's total expenditure by its population

Source: Authors' elaboration on China Statistical Yearbook, 2014 
Table B Per capita income and expenditure of rural households

\begin{tabular}{|c|c|c|c|c|c|c|c|}
\hline & 1990 & 1995 & 2000 & 2010 & 2011 & 2012 & 2013 \\
\hline $\begin{array}{l}\text { Per Capita } \\
\text { Annual } \\
\text { Income* (yuan) }\end{array}$ & 686.3 & $1,577.7$ & $2,253.4$ & $5,919.0$ & $6,977.3$ & $7,916.6$ & $8,895.9$ \\
\hline $\begin{array}{l}\text { Per Capita } \\
\text { Annual } \\
\text { Consumption** } \\
\text { (yuan) } \\
\text { Of which: }\end{array}$ & 374.7 & 859.4 & $1,284.7$ & $3,859.3$ & $4,733.4$ & $5,414.5$ & $6,112.9$ \\
\hline $\begin{array}{l}\text { Of which: } \\
\text { Food }\end{array}$ & 155.9 & 353.2 & 464.3 & $1,313.2$ & $1,651.3$ & $1,863.1$ & $2,054.5$ \\
\hline Clothing & 44.0 & 88.7 & 95.2 & 263.4 & 341.1 & 396.1 & 437.7 \\
\hline Residence & 81.2 & 147.9 & 231.1 & 801.4 & 930.2 & $1,054.2$ & $1,169.3$ \\
\hline $\begin{array}{l}\text { Household } \\
\text { Facilities and } \\
\text { Articles }\end{array}$ & 30.7 & 68.1 & 74.4 & 233.5 & 308.6 & 341.4 & 384.5 \\
\hline $\begin{array}{l}\text { Transport and } \\
\text { Communications }\end{array}$ & 8.4 & 33.7 & 93.1 & 461.1 & 547.0 & 652.8 & 795.8 \\
\hline $\begin{array}{c}\text { Education, Culture } \\
\text { and Recreation }\end{array}$ & 31.3 & 102.4 & 186.7 & 366.7 & 396.4 & 445.5 & 485.6 \\
\hline Health Care & 19.0 & 42.5 & 87.6 & 326.0 & 436.8 & 513.8 & 613.9 \\
\hline $\begin{array}{l}\text { Others } \\
\text { Cash }\end{array}$ & 4.3 & 23.1 & 52.5 & 94.0 & 122.0 & 147.5 & 171.6 \\
\hline \multicolumn{8}{|l|}{$\begin{array}{l}\text { Consumption } \\
\text { Expenditure } \\
\text { index }=100 \text { ) }\end{array}$} \\
\hline Food & 58.8 & 58.6 & 49.1 & 41.1 & 40.4 & 39.3 & 37.7 \\
\hline Clothing & 7.8 & 6.9 & 5.7 & 6.0 & 6.5 & 6.7 & 6.6 \\
\hline Residence & 17.3 & 13.9 & 15.5 & 19.1 & 18.4 & 18.4 & 18.6 \\
\hline $\begin{array}{l}\text { Household } \\
\text { Facilities and } \\
\text { Articles }\end{array}$ & 5.3 & 5.2 & 4.5 & 5.3 & 5.9 & 5.8 & 5.8 \\
\hline $\begin{array}{l}\text { Transport and } \\
\text { Communications }\end{array}$ & 1.4 & 2.6 & 5.6 & 10.5 & 10.5 & 11.0 & 12.0 \\
\hline $\begin{array}{l}\text { Education, Culture } \\
\text { and Recreation }\end{array}$ & 5.4 & 7.8 & 11.2 & 8.4 & 7.6 & 7.5 & 7.3 \\
\hline Health Care & 3.3 & 3.2 & 5.2 & 7.4 & 8.4 & 8.7 & 9.3 \\
\hline Others & 0.7 & 1.8 & 3.1 & 2.1 & 2.3 & 2.5 & 2.6 \\
\hline
\end{tabular}

Source: Authors' elaboration on China Statistical Yearbook, 2014 
Table $C$ Top 10 Chinese food and beverage companies

\begin{tabular}{ll}
\hline Company & Field of activities \\
\hline No. 1. COFCO Group & $\begin{array}{c}\text { Products and services in the agricultural } \\
\text { sector and food industry in China } \\
\text { Dairy company (processing and } \\
\text { manufacturing of milk products, } \\
\text { including ice cream, milk powder, milk } \\
\text { tea powder, sterilized milk and fresh } \\
\text { mo. 2. Inner Mongolia Yili Industrial } \\
\text { milk under 'Yili' brand) } \\
\text { Meat processing company (including } \\
\text { pig raising, consumer meat products, } \\
\text { flavoring products, and logistics) } \\
\text { Manufacturing and distribution company } \\
\text { of dairy products and ice cream }\end{array}$ \\
No. 4. China Mengniu Dairy Co Ltd & $\begin{array}{l}\text { Food and beverages company } \\
\text { Non-alcoholic beverage producer } \\
\text { No. 5. Bright Food (Group) Corp Ltd } \\
\text { No. 6. Hangzhou Wahaha Group Co Ltd } \\
\text { No. 7. Wuliangye Yibin Co Ltd }\end{array}$ \\
No. 8. Tsingtao Breweries Co Ltd & $\begin{array}{l}\text { Beer producer } \\
\text { Producer of Maotai liquor, together } \\
\text { with the production and sale of other }\end{array}$ \\
No. 9. Kweichow Moutai Co Ltd & beverages, food and packaging material \\
No. 10. Yurun Group Ltd & Meat supplier
\end{tabular}

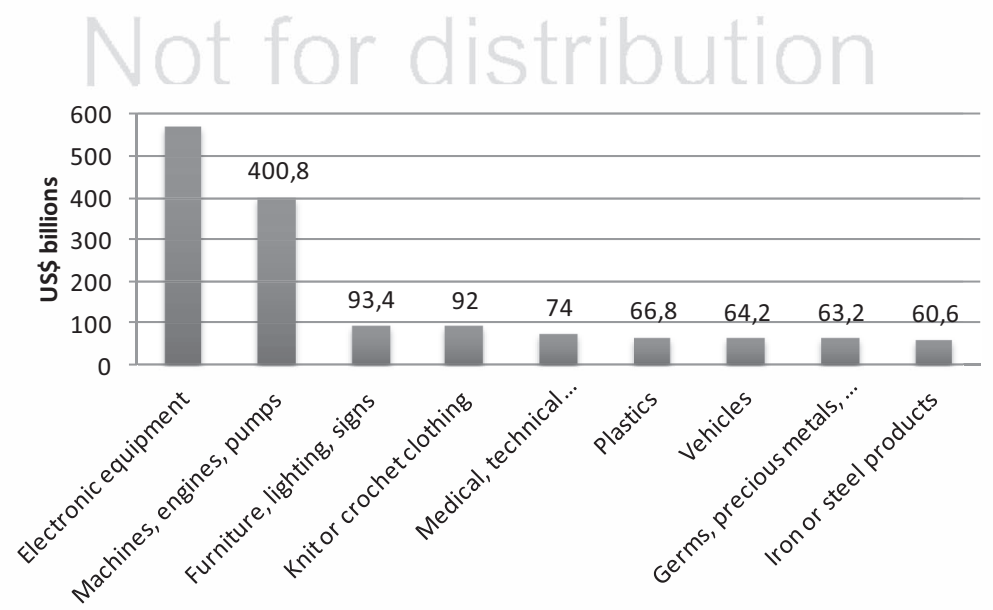

Type of products

Figure A Top 10 export products in 2014

Source: Authors' elaboration on data from www.worldstopexports.com/chinas-top-10-exports/1952 


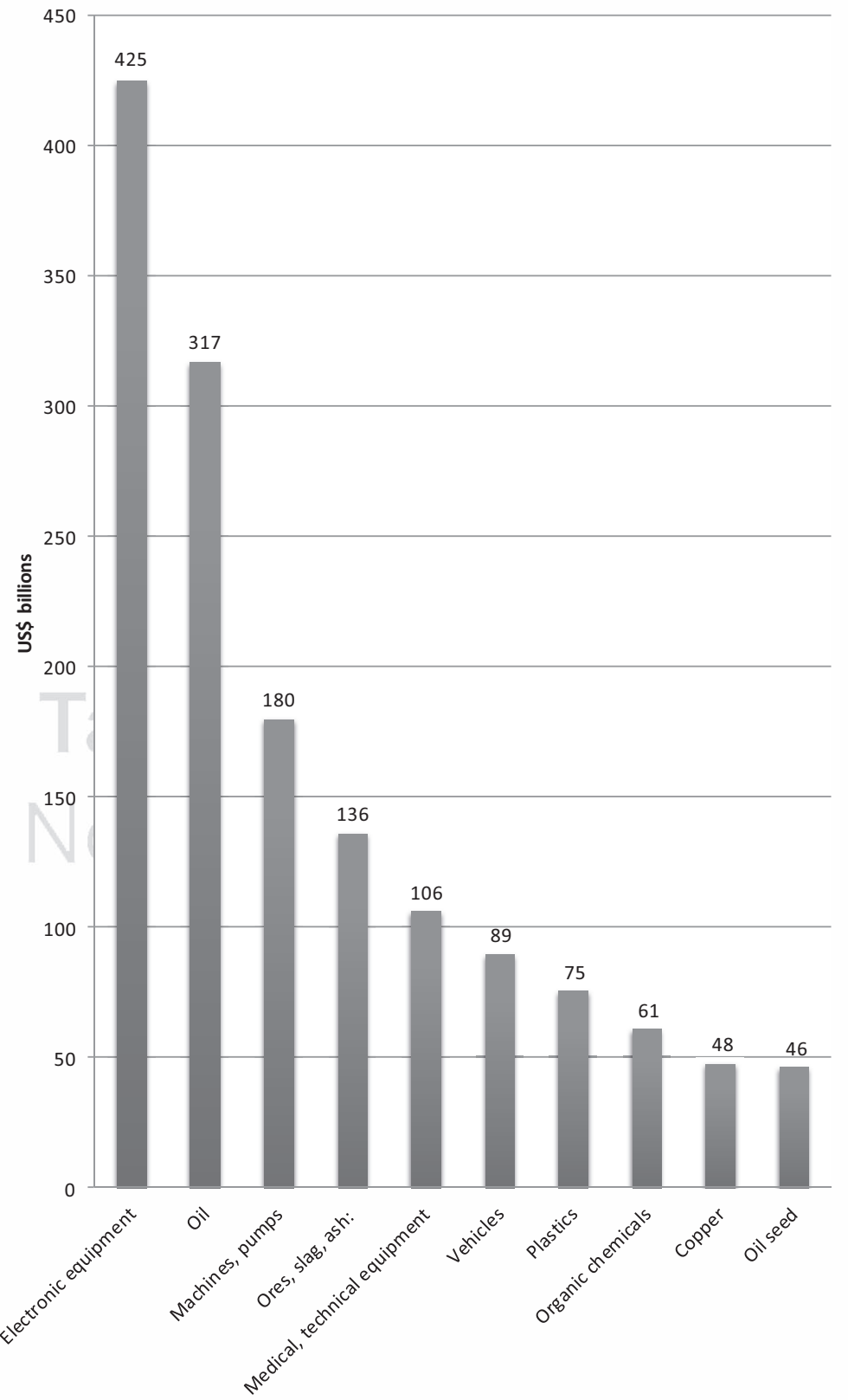

Figure B Top 10 import products in 2014

Source: Authors' elaboration on data from www.worldstopexports.com/chinas-top-10-imports/4017 


\section{Notes}

1 Some difficulties occurred when analyzing data regarding Chinese arable land size, because of discrepancies between data from different sources: the final decision was to use FAOSTAT data which provide a time series on this topic, even if they provide a lower figure than that reported by the Chinese government.

2 China began promoting the use of birth control and family planning with the establishment of the People's Republic in 1949, first on a voluntary basis and then, from 1980, S2013, there has been a gradual relaxation of China's family planning laws that already allowed minority ethnic families and rural couples whose firstborn was a girl to have more than one child. In 2015 China announced the intention to scrap its one-child policy, allowing all couples to have two children for the first time since draconian family planning rules were introduced more than three decades ago.

3 The GINI index measures the extent to which the distribution of income (or, in some cases, consumption expenditure) among individuals or households within an economy deviates from a perfectly equal distribution. A Lorenz curve plots the cumulative percentages of total income received against the cumulative number of recipients, starting with the poorest individual or household. The GINI index measures the area between the Lorenz curve and a hypothetical line of absolute equality, expressed as a percentage of the maximum area under the line. Thus a GINI index of 0 represents perfect equality, while an index of 100 implies perfect inequality.

4 During the National Video Conference on Permanent Basic Farmland Designation and Protected Agriculture Land Management, jointly organized by the Ministry of Agriculture and the Ministry of Land and Resources and held on 5 January 2015, the premier, Li Keqiang stressed that China must maintain its farmland above the minimum threshold of 120 million hectares, a 'red line' which must be observed. Furthermore, China must attach equal importance to the quantity and quality of farmland to ensure its food security and specific policies must be introduced for these purposes.

5 There are two protection levels: the first consists of high-quality farmland that cannot be converted to non-agricultural use in the long term; the second level consists of good-quality farmland that cannot be converted to non -agricultural use in the planned periods (usually five or 10 years) (Ding, 2003).

6 Hypermarkets: the major hypermarkets are Carrefour, Wal-Mart, Metro, Lotus, Auchan, and Tesco; Supermarkets: the major supermarkets are Lianhua, Wellcome, ParknShop, China Resources Vanguard and Suguo; Specialty Supermarket Stores and Boutique Stores: the major specialty supermarkets are City Shop Supermarket (Shanghai), City-Super, CRV Ole, BHG (Beijing Hualian Supermarket), Hisense Plaza in Qingdao, and Jin Bou Da in Zhengzhou); Convenience Stores: (such as 7-Eleven, Family Mart (Japan), ItoYokado (Japan), Sincere (Hong Kong), C-Store (Taiwan), and Lawson's (Sino-Japan JV); Online Sales: (one company, Taobao reportedly has a 75\% market share at the moment); there are also traditional markets.

7 Per capita consumption expenditure is the market value of all goods and services, including durable products (such as cars, washing machines, and home computers), purchased by households. It is calculated by dividing the area's total expenditure by its population

8 In the first case the share of consumption on total income has been increasing over the years $(54.6 \%$ in $1990,68.7 \%$ in 2013$)$; in the second the consumption share has been decreasing (from $84.3 \%$ in 1990 to $61 \%$ in 2013).

9 Less conspicuous than over the previous period (from $49.1 \%$ to $41.1 \%$ in rural areas and from $39.4 \%$ to $35.7 \%$ in urban areas).

10 The four pests to be eliminated were: rats, sparrows, flies, mosquitos.

11 The plan identifies seven strategic industries which are expected to benefit from special incentives and funding:

- Energy conservation and environmental protection

- Next generation telecommunications technology 
- Biotechnology

- High-end equipment manufacturing

- New energy

- New materials

- Clean energy vehicles

12 It promotes 'the strictest system of water resource management', setting targets for total water use, water use efficiency, and ambient water quality for a number of benchmark years to 2030 .

13 These headline policies are augmented by increased investment, including RMB 1.8 trillion in 2011-2015, primarily for irrigation infrastructure improvements, rural clean water delivery, and reservoir enhancements (More, 2013).

14 Source that collects data about the agreements involving agricultural land.

15 China was one of the earliest countries to use pesticides (Zhang, 2013) and though on the one hand, throughout China pesticides have killed crop pests, on the other hand, they have also poisoned farmers and consumers.

16 In China, the major harmful factors include toxic animals and plants (e.g. puffer fish and toadstools), pathogenic microorganisms (e.g. Salmonella and Vibrio Parahaemolyticus), and chemical contamination (e.g. pesticide and veterinary drug residues). For example, of 174 food safety incidents reported in 2012 in China, most were caused by toxic animals or plants $(41.4 \%)$, followed by pathogenic microorganisms $(32.8 \%)$, and chemical contamination $(12.1 \%)$.

\section{References}

ANZ Agribusiness (2013). Feeding the dragon: The modernization of China's food industry, www.anzbusiness.com/content/dam/anz-superregional/AgricultureInsightsChina Food.pdf.

Bergère, M. C. (2000). La Chine de 1949 à nos jours. Paris: Armand Colin, III edition.

Brown, L. R. (1995). Who Will Feed China? A Wake Up Call for a Small Planet, The Worldwatch Environmental Alert Series. New York: Norton \& Co.

Cao, L., Tian, W., Wang, J., Malcolm, B., Liu, H., and Zhou, Z. (2013). Recent food consumption trends in China and trade implications to 2020. Australasian Agribusiness Review, 21, 15-44. www.agri-food.info/review/2013/Cao_et_al.pdf.

China National Bureau of Statistics (2014). China statistical yearbook, www.stats.gov.cn/ tjsj/ndsj/2014/indexeh.htm.

Circle of Blue (2013). Scoping water and energy pollution Nexus in Urumqi and Qingdao for preparing PRC's Ministry of Environmental Protection Co-Control Program, www.circleofblue.org/waternews/wp-content/uploads/2013/09/Water-Energy-NexusFinalReport_5.pdf.

Cui, S., and Kattumuri, R. (2011). Cultivated land conversion in China and the potential for food security and sustainability. Working Paper 35, Asia Research Centre, London School of Economics \& Political, www.lse.ac.uk/asiaResearchCentre/_files/ARCWP35CuiKattumuri.pdf, accessed 2 November 2014.

Ding, C. (2003). Land policy reform in China: Assessment and prospects. Land Use Policy, 20(2), 109-120.

Ding, C. (2007). Policy and praxis of land acquisition in China. Land Use Policy, 24(1), $1-13$.

DuPont (2013). China's insatiable appetite for change. Fortune Global Forum, 6-8 June, Chengdu, China, http://www2.dupont.com/Media_Center/en_US/assets/downloads/pdf/ DuPont_White_Paper_Food_Security_China.pdf, accessed 14 July 2014. 
Euromonitor International (2014). China in 2030: The future demographic, www.euromonitor. com/china-in-2030-the-future-demographic/report.

European Commission (2012). EU-China geographical indications - "10 plus 10" project is now complete, http://europa.eu/rapid/press-release_IP-12-1297_en.htm?locale=en.

European Commission (2013). Geographical-indications, http://ec.europa.eu/trade/policy/ accessing-markets/intellectual-property/geographical-indications/

EUSME Centre (2015). The food and beverage market in China, www.eusmecentre.org. $\mathrm{cn} /$ report/food-beverage-market-china.

FAO (2013). 2000 World census of agriculture: Analysis and international comparison of the results 1996-2005, www.fao.org/fileadmin/templates/ess/ess_test_folder/World Census_Agriculture/Publications/WCA_2000/Census13.pdf.

FAO (2015). Status of the world soil resources. Main Report, www.fao.org/3/a-bc599e.pdf.

FAO Aquastat (2014). Water resources indicators, www.fao.org/nr/water/aquastat/water_ res/index.stm.

FAOSTAT (2015). Agri-environmental indicators, http://faostat3.fao.org/download/E/*/E.

Fuller, F., Beghin, J., De Cara, S., Fabiosa, J., Fang, C., and Matthey, H. (2001). China's accession to the WTO: What is at stake for agricultural markets? CARD Working Papers. Paper 310, http://lib.dr.iastate.edu/card_workingpapers/310.

Hanjira, M. A., Mu, J., and Khan, S. (2008). Water Management and Crop Production for Food Security in China: A Review. Wagga Wagga: Charles Sturt University, Elsevier editions, http://bwl.univie.ac.at/fileadmin/user_upload/lehrstuhl_ind_en_uw/lehre/ss11/ Sem_Yuri/Agr-water.pdf.

Huang, J., Jun, Y., Xu, Z., Rozelle, S., Li, N. (2007). Agricultural trade liberalization and poverty in China. China Economic Review, Volume 18, Issue 3, 2007, 244-265, ISSN 1043-951X, http://www.sciencedirect.com/science/article/pii/S1043951X07000120

IMF (2015). World Economic Outlook, www.imf.org/external/pubs/ft/weo/2015/01/pdf/ text.pdf.

Lam, H. M., Remais, J., Fung, M. C., Xu, L., and Sun, S. S. M. (2013). Food supply and food safety issues in China. The Lancet, 381(9882), 2044-2053. Issues in China. Iran J Public Land matrix, www.landmatrix.org/en/

Lee, M., Park, D., and Ramayand, A. (2016). How growth deceleration in the People's Republic of China affects other Asian economies. An empirical analysis. ADB economics working paper series n. 484, www.adb.org/sites/default/files/publication/183899/ ewp-484.pdf.

Li, T. (2014). The Celestial Empire goes urban. Brics Business Magazine, www.bricsmagazine. com/en/articles/the-celestial-empire-goes-urban.

Lin, J. Y. (1992). Rural reforms and agricultural growth in China. The American Economic Review, 82(1).

Liu, X., Wang, X., and Xin, X. (2012). Did agricultural technological changes affect China's regional disparity? China Agricultural Economic Review, 4(4), 440-449. doi:10.1108/17561371211284803.

More, S. (2013). Issue brief: Water resource issues, policy and politics in China, www. brookings.edu/research/papers/2013/02/water-politics-china-moore.

Ni, H. (2013). Analisi delle politiche di supporto all'agricoltura cinese, Report No. 47, International Centre for Trade and Sustainable Development (ICSTD), www.cicos. agri.gov.cn/Upload/Files/NewsAttatches/2353/china_paper_v4.-.201351511010.pdf, accessed 1 November 2014.

OECD, FAO (2013). Agricultural Outlook 2013-2022: Highlights, www.oecd.org/site/ oecd-faoagriculturaloutlook/highlights-2013-EN.pdf, accessed 22 July 2014. 
Park, A. (2009). Agricultural development in China: Lessons for http://users. ox.ac.uk/ econstd/Brief_Park\%20_rev_pdf.

Ren, T. (2008).China agriculture: Challenge and countermeasures, https://sustainabledevelopment.un.org/content/documents/ren_5may_agriculture.pdf.

Smaller, C., Wei, Q., and Yalan, L. (2012). Farmland and water: China invests abroad. IISD Report, International Institute for Sustainable Development, www.iisd.org/ pdf/2012/farmland_water_china_invests.pdf.

USDA (2015). Gain report. China - Peoples Republic of food service - hotel restaurant institutional HRI food service sector annual report, ain.fas.usda.gov/Recent GAIN Publications/Food Service - Hotel Restaurant Institutional_Guangzhou ATO_China - Peoples Republic of_2-10-2015.pdf.

WenJun Zhang, FuBin Jiang, and JianFeng Ou (2011). Global pesticide consumption and pollution: With China as a focus. Proceedings of the International Academy of Ecology and Environmental Sciences.

WTO (2015). Statistics, trade and tariff data, www.wto.org/english/res_e/statis_e/statis_e. htm. Xiwen, C. (2006). Conflicts and problems facing China's current rural reform and development, Chapter 4 in: Dong X.-y, Song S., and Zhang X. (eds.), China's Agricultural Development. Aldershot: Ashgate Publishing Limited

Zanier, V. (2010). Dal grande esperimento alla società armoniosa, trent'anni di riforme economiche per costruire una nuova Cina. Milano: Franco Angeli.

Zhang, H. (2013). Behind China's "Grain Miracle": More than Meets the Eye? RSIS Commentaries No. 028/2013, S. Rajaratnam School of International Studies, Nanyang, www. rsis.edu.sg/wp-content/uploads/2014/07/CO13028.pdf, accessed 13 November 2014.

Zhao, G. (1986). Man and Land in Chinese History: An Economic Analysis. Stanford: Stanford University Press.

Zolin, M. B., and Luzi, L. (2013). Unexpected and growing interest in land investments? The Asian case, in: Andreosso O'Callaghan, B., Jaussaud, J., and Zolin, M. B. (eds.), Economic Integration in Asia Towards the Delineation of a Sustainable Path. Basingstoke: Palgrave MacMillan, 78-98. 